\title{
The Process: Brexit and the Anatomy of Article 50
}

\author{
Paul Craig
}

The UK withdrawal process from the EU is framed by Article $50 \mathrm{TEU}$. There has been significant discussion of particular issues, such as revocability. There has not, however, been a more holistic examination of this Treaty provision, which analyses the stages of withdrawal from a UK and EU perspective. There are three stages in Article 50, which involve contestable issues of process and substance: triggering, negotiation, and outcome. Article 50 provides that,

1. Any Member State may decide to withdraw from the Union in accordance with its own constitutional requirements.

2. A Member State which decides to withdraw shall notify the European Council of its intention. In the light of the guidelines provided by the European Council, the Union shall negotiate and conclude an agreement with that State, setting out the arrangements for its withdrawal, taking account of the framework for its future relationship with the Union. That agreement shall be negotiated in accordance with Article 218(3) of the Treaty on the Functioning of the European Union. It shall be concluded on behalf of the Union by the Council, acting by a qualified majority, after obtaining the consent of the European Parliament.

3. The Treaties shall cease to apply to the State in question from the date of entry into force of the withdrawal agreement or, failing that, two years after the notification referred to in paragraph 2, unless the European Council, in agreement with the Member State concerned, unanimously decides to extend this period.

4. For the purposes of paragraphs 2 and 3, the member of the European Council or of the Council representing the withdrawing Member State shall not participate in the discussions of the European Council or Council or in decisions concerning it.

A qualified majority shall be defined in accordance with Article 238(3)(b) of the Treaty on the Functioning of the European Union.

5. If a State which has withdrawn from the Union asks to rejoin, its request shall be subject to the procedure referred to in Article 49.

Stage 1 is the triggering stage in Article 50(1) TEU, whereby a Member State decides to withdraw in accord with its own constitutional requirements, and this includes the first sentence of Article 50(2), which is the notification of that intention to the European Council. 
Stage 2 concerns negotiation and is contained in Article 50(2). The negotiations are conducted in the light of guidelines provided by the European Council. There is to be a withdrawal agreement negotiated in accordance with Article 218(3) TFEU. Article 50(2) also envisages another agreement concerning future relations between the state that has withdrawn and the EU.

Stage 3 concerns outcomes, and is dealt with in the last sentence of Article 50(2), and in Articles 50(3)-(4). Treaty rights and obligations apply to the state until the withdrawal agreement is concluded, or until two years from the date of notification, unless the European Council unanimously agrees to extend that period. Stage 3 may be affected by the possibility of revoking the notice of withdrawal prior to the end of two years; and by the possibility of a transition agreement.

\section{Triggering Article 50}

\section{(a) Process}

Autumn 2016 was occupied with legal contestation as to the process for triggering Article 50, culminating in the decision in Miller. ${ }^{1}$ The UK Supreme Court decided that the executive could not trigger withdrawal through the royal prerogative. Statutory approval was a constitutional condition precedent under UK law before the exit process could begin. There was a powerful dissent, most especially from Lord Reed. I believe that the majority was nonetheless correct, but the result was not simple or self-evident. This is not the place to rehearse these complex arguments; my detailed views can be found elsewhere. ${ }^{2}$

\footnotetext{
${ }^{1}$ R. (on the application of Miller) $v$ Secretary of State for Exiting the European Union [2017] UKSC 5.

${ }^{2}$ P Craig, 'Miller, Structural Constitutional Review and the Limits of Prerogative Power' [2017] PL forthcoming.
} 
Suffice it to note that the Miller dispute was, as both the Divisional Court and the Supreme Court emphasized, about the UK constitutional process requirements to be satisfied before exit could begin. The courts were not adjudicating the substantive issue of whether it was desirable for the UK to exit the EU.

Suffice it to note also that this was a constitutional fight that never had to happen. Subject to limited exceptions, it takes two to litigate The salient issue is why the government fought the action. It might be contended that the government believed that it should be able to trigger Article 50, through the prerogative. This argument is, however, relatively weak, since government lawyers would have told the Prime Minister that this was not an open and shut case, more especially because they did not wish to argue that Article 50 was revocable and thus could not easily rebut the claimant's argument that triggering of Article 50 would terminate rights derived from EU law. It might alternatively be argued that the Prime Minister was worried by backbench revolt if a Bill to authorize withdrawal were placed before Parliament, but this was unlikely for reasons explicated below.

The reality is that the Prime Minister could have secured her aims without litigation. Theresa May could have said in October 2016 that while she did not accept that she had, as a matter of law, to secure parliamentary authorization before triggering Article 50, she would nonetheless place the appropriate Bill before Parliament. The statute would have been duly enacted well before Christmas without litigation.

\section{(b) Substance}

The European Union (Notification of Withdrawal) Act 2017 has 134 words, the operative section 1(1) stating that the "Prime Minister may notify, under Article 50(2) of the Treaty on European Union, the United Kingdom's intention to withdraw from the EU'. The Bill was placed before Parliament the day after the Supreme Court's decision. Truth to tell, it is highly 
likely that the government had a draft of such legislation in its top drawer considerably earlier. The notes accompanying the Bill were exiguous, forcefully exemplified by the statement that post-legislative scrutiny was not required, since "the impact of the Bill will be both clear and limited". 3 A greater mismatch between language and reality would be hard to find.

The government accepted that it would have to gain statutory approval, but rejected constraints on its negotiating position. Thus it refused procedural constraints designed to impose reporting requirements during the negotiation process, and rejected also the amendment to the Bill in the House of Lords ${ }^{4}$ whereby the government would have been legally obliged to place a withdrawal agreement before Parliament prior to accepting or rejecting it. ${ }^{5}$ It gave a political assurance that it would do this, while making clear that if Parliament rejected a withdrawal agreement, then the UK would exit the EU without an agreement and default to World Trade Organization rules. ${ }^{6}$ In similar vein it denied a substantive House of Lords' amendment to protect the rights of EU citizens living in the UK. The amendments failed in the House of Commons through a foreseeable concatenation of political circumstance: the great majority of Tories who voted to remain in the EU were unwilling to press amendments on the government; and the official Labour position was that it would not do anything to jeopardize ultimate enactment of the Bill, thereby reducing its political leverage in parliamentary debate to something approximating to zero.

\footnotetext{
${ }^{3}$ European Union (Notification of Withdrawal) Bill 2017, para. 14. See, for a powerful critique, M Freedland

${ }^{4}$ Hansard 7 March 2017, Vol. [779] Col. [1250].

${ }^{5}$ Hansard 13 March 2017, Vol. [623] Col. [38].

${ }^{6}$ Prime Minister Theresa May sets out the Plan for Britain, including the 12 priorities that the UK government will use to negotiate Brexit, January 17 2017, p. 5, https://www.gov.uk/government/speeches/the-governmentsnegotiating-objectives-for-exiting-the-eu-pm-speech ; Hansard 7 Feb 2017, Vol. [621] Col. [272].
} 
The outcome of this saga may have been foreseeable, but it was not preordained given our foundational constitutional axioms. Sovereignty resides with Parliament, and has done so for circa 400 years. It does not reside with the executive. It is therefore constitutionally unarguable that Parliament could, at any time since 23 June 2016, have enacted a statute requiring the government to seek its approval before triggering Article 50. The statute would have trumped the prerogative, and Parliament could have imposed whatever procedural or substantive constraints that it felt were warranted. Parliament did not therefore need to await rescue by the courts. ${ }^{7}$

This begs the question as to why Parliament was quiescent in this respect, to which the answer is eclectic. Some MPs might genuinely have felt that the issue should, for reasons of principle, be left to the executive; others, particularly, hard Brexiteers, were committed functionally to the prerogative, since they were concerned at attempts to undo their victory in Parliament. The principal explanation was rather different. MPs were fearful of backlash from their constituents who had voted to leave, a fear reinforced by likely reaction from certain sections of the media. Much easier for MPs to remain largely silent on this, such that demands for Parliamentary voice rarely rose to whisper let alone clamour, and rely on the courts to give Parliament voice without the attendant political dangers of actively seeking it. Viewed from this perspective, the House of Commons' unwillingness to force amendments on the government was a continuation of this same theme.

\section{Negotiation of Withdrawal and Future Relations}

\footnotetext{
${ }^{7}$ I am fully mindful of the power wielded by the executive over the legislative process. It does not, however, alter the constitutional point made above. It is, moreover, doubtful in political terms whether the executive could have prevented serious consideration of such a Bill if MPs across the political divide had brought it to the House.
} 


\section{(a) Process}

\section{(i) EU Level}

Article 50(2) provides for negotiation of a withdrawal agreement, "taking account of the framework for its future relationship with the Union". There is a formal and informal dimension to this second stage of withdrawal.

The formal stage is set out in Article 50(2). The European Council provides the guidelines for negotiation, which frame discussions leading to the withdrawal agreement. It is the Commission, as affirmed by Article 218(3) TFEU, that conducts the detailed negotiation. The European Parliament has no formal role, but since it has a veto on the withdrawal agreement, its views will perforce be taken into account during the negotiation. It is the Council acting by qualified majority that concludes the agreement, after obtaining the consent of the European Parliament.

The informal dimension to the process is equally important. Foremost in this regard is the ordering of the negotiations, whether discussion of withdrawal and future trade relations should proceed in parallel, or whether there should be a phased ordering, such that discussion about the latter only commences when there has been sufficient progress on the former. The UK strongly favours parallel discussion, while the EU advocates phased ordering. The difference is readily explicable, since it affects the balance of power within the negotiations: parallelism would enable the UK to engage in trade-offs between the terms of withdrawal and future trade relations; the phased approach means that the EU can refuse to discuss trade relations until it has secured an acceptable withdrawal deal. The difference of view is apparent from the relevant documentation. 
The UK's position was initially articulated in the Prime Minister's Lancaster House speech. ${ }^{8}$ She emphasized the need for discussions concerning withdrawal and future trade to proceed in tandem when stating that "I want us to have reached an agreement about our future partnership by the time the 2-year Article 50 process has concluded". 9 This sentiment was reinforced in the White Paper on Exit from the EU, ${ }^{10}$ which stated that it was "in no one's interests for there to be a cliff-edge for business or a threat to stability, as we change from our existing relationship to a new partnership with the EU". ${ }^{11}$ The point was reaffirmed in the Prime Minister's notification of withdrawal letter of March $292017,{ }^{12}$ which stated that "it is necessary to agree the terms of our future partnership alongside those our withdrawal from the European Union", ${ }^{13}$ a sentiment that was thrice repeated in the letter. ${ }^{14}$

The response from President Tusk to the Prime Minister's letter was succinct in its rejection of parallelism. He outlined the fundamental principles that would inform the negotiations, which were: minimization of disruption caused by UK withdrawal; securing agreement on the rights of EU citizens living in the UK; ensuring that the UK honours its

\footnotetext{
${ }^{8}$ Lancaster House Speech (n 6).

${ }^{9}$ Ibid 10.

${ }^{10}$ The United Kingdom's Exit from and New Partnership with the European Union, Cm 9417 (2017).

${ }^{11}$ Ibid [12.2].

${ }^{12}$ Formal Notification of Withdrawal, 29 March 2017, https://www.gov.uk/government/publications/primeministers-letter-to-donald-tusk-triggering-article-50

${ }^{13}$ Ibid 2.

${ }^{14} \operatorname{Ibid} 4,5,6$.
} 
financial commitments; and avoiding a hard border between Northern Ireland and Ireland. He then continued in the following vein. ${ }^{15}$

These four issues are all part of the first phase of our negotiations. Once, and only once we have achieved sufficient progress on the withdrawal, can we discuss the framework for our future relationship. Starting parallel talks on all issues at the same time, as suggested by some in the UK, will not happen.

President Tusk reiterated this position before the European Council meeting in April 2017, stating that "before discussing our future, we must first sort out our past". ${ }^{16}$ The German Chancellor, Angela Merkel, reaffirmed this position, ${ }^{17}$ as did the European Parliament. ${ }^{18}$ The European Council formally endorsed the negotiation guidelines on 29 April $2017^{19}$ and adopted the phased approach. The first phase is concerned with the withdrawal agreement, the "disentanglement of the United Kingdom from the European Union". ${ }^{20}$ The second phase concerns future trade relations, which can only be finalized after the UK has left the EU; an overall understanding of the framework of this relationship may be agreed during the second phase, but "preliminary and preparatory discussions to this end" 21 can only occur when the European Council decides that sufficient progress has been made towards

15 Remarks by President Donald Tusk on the next steps following the UK notification, http://dsms.consilium.europa.eu/952/Actions/Newsletter.aspx?messageid=11790\&customerid=16061\&passwor d=enc_3936444345424338_enc

16 Invitation letter by President Donald Tusk to the members of the European Council, http://www.consilium.europa.eu/en/press/press-releases/2017/04/28-tusk-invitation-letter-euco-art50/

${ }^{17}$ BBC News, 27 April 2017, http://www.bbc.co.uk/news/world-europe-39730326

18 Red Lines on Brexit Negotiations, http://www.europarl.europa.eu/news/en/news$\underline{\text { room/20170329IPR69054/red-lines-on-brexit-negotiations }}$

\footnotetext{
${ }^{19}$ European Council, Brussels, 29 April 2017, EUCO XT 20004/17.

${ }^{20}$ Ibid [4].

${ }^{21}$ Ibid [5].
} 
"reaching a satisfactory agreement on the arrangements for an orderly withdrawal". ${ }^{22}$ The guidelines have, as will be seen below, been reaffirmed and rendered more specific in the Commission's negotiating mandate. ${ }^{23}$

(ii) UK Level

There are three important process issues at the UK level. The first concerns input by Parliament during the negotiations. The executive is under no legal obligation to keep Parliament informed during the negotiations. While the government has stated that it will "continue to build a national consensus around our negotiating position by listening and talking to as many organisations, companies and institutions as possible", ${ }^{24}$ it remains to be seen how far the executive chooses to inform Parliament during this period, and how far information is leaked. Parliament has established a select committee on Exiting the European Union. ${ }^{25}$ Its brief is to consider the administration, expenditure and policy of the Department for Exiting the European Union, and it has published three reports thus far. There is in addition the House of Lords' Select Committee on the EU, which has undertaken studies on withdrawal, ${ }^{26}$ and the House of Lords' Constitution Committee, which has analysed issues raised by the EU Withdrawal Bill and the Great Repeal Bill. ${ }^{27}$

\footnotetext{
${ }^{22}$ Ibid [5].

${ }^{23}$ Recommendation for a Council Decision authorizing the Commission to open negotiations with the UK setting out the arrangements for its withdrawal from the EU, $\operatorname{COM}(2017) 218$ final.

${ }^{24}$ White Paper (n 10) [1.6].

25 http://www.parliament.uk/business/committees/committees-a-z/commons-select/exiting-the-european-unioncommittee/

${ }^{26} \mathrm{http} / / / \mathrm{www}$. parliament.uk/business/committees/committees-a-z/lords-select/eu-select-committee-/ http://www.parliament.uk/business/committees/committees-a-z/lords-select/constitution-
} committee/publications/ 
The second process issue concerns the role of the devolved areas in the negotiations. The Supreme Court decided that there was no legal obligation to secure the consent of the devolved legislatures before triggering Article 50. ${ }^{28}$ Engagement of the devolved administrations is organized through the Joint Ministerial Committee (JMC), ${ }^{29}$ and the JMC sub-committee on EU Negotiations $(\mathrm{JMC}(\mathrm{EN})) .{ }^{30}$ The official government line is that the devolved administrations are fully engaged in Brexit preparations; that the deal will work for the whole UK; and that it will take into account the interests of the devolved regions. ${ }^{31}$

This does not, however, reflect political reality. There have been real tensions, because of differing views on hard and soft Brexit. The government opted for the former, ${ }^{32}$ the devolved administrations for the latter. Thus Nicola Sturgeon, the Scottish First Minister, consistently maintained that Scotland's priority was to remain in the single market, ${ }^{33}$ and this became Scottish government policy. ${ }^{34}$ The same view was expressed by Wales. ${ }^{35}$ The tensions were evident when the Prime Minister gave her Lancaster House speech, in which

\footnotetext{
${ }^{28} \operatorname{Miller}(\mathrm{n} 1)$.

${ }^{29}$ Chaired in plenary by the Prime Minister and attended by the First Ministers of Scotland and Wales and the First and deputy First Ministers of Northern Ireland.

${ }^{30}$ Chaired by the Secretary of State for Exiting the European Union, with members from each of the UK devolved administrations.

${ }^{31}$ White Paper (n 10) [3.1.]

${ }^{32}$ White Paper (n 10) [8.1-8.44]; Notification of Withdrawal (n 12) 4.

33 https://firstminister.gov.scot/fm-highlights-importance-of-single-market/ ; https://firstminister.gov.scot/joint$\underline{\text { ministerial-committee-on-eu-referendum/ ; https://firstminister.gov.scot/3265-2/ }}$
}

34 Scotland's Place in Europe, Scottish Government, December 2016, http://www.gov.scot/Resource/0051/00512073.pdf

35 Securing Wales' Future, Transition from the European Union to a New Relationship with Europe, Welsh Government, January 2017 https://beta.gov.wales/sites/default/files/201702/31139\%20Securing\%20Wales\%C2\%B9\%20Future Version\%202_WEB.pdf 
she opted for hard Brexit, two days before a JMC meeting, without having discussed Scotland's policy document released a month earlier. It prompted an angry response from Michael Russell, the Scottish Minister, who stated that Scotland "must not be treated with contempt but as an equal partner in the negotiating process"; that "Scotland overwhelmingly rejected a hard Brexit"; and that it was "extremely disappointing that the Prime Minister chose to disregard the process and make a significant announcement about her position two days before the JMC even considered our paper". ${ }^{36}$ As Sionadh Douglas-Scott noted, the reaction to JMC (EN) meetings by the devolved administrations has been one of "frustration that their views were not being taken into account". ${ }^{37}$ The Westminster government's treatment of the devolved administrations was further in evidence in the withdrawal letter which, while acknowledging Northern Ireland as a special case, made no mention of special arrangements for Scotland and Wales. ${ }^{38}$

The third process issue concerns the government's approach if it does not like the way in which the negotiations are going. Much has been made of the Prime Minister's statement that "no deal for Britain is better than a bad deal for Britain". ${ }^{39}$ This has been taken to mean that if the withdrawal agreement is not to the liking of the UK, it may simply walk away, with the consequence that it will default to WTO rules. The statement was made in the context of a trade deal that was not to the liking of the UK. ${ }^{40}$ The UK documents are, however, predicated on parallelism. If this assumption were true a decision to leave the negotiating table could be based on conclusions as to the desirability of the overall package on offer, withdrawal and trade agreement combined. Parallelism is, however, very unlikely to occur. Even if trade

\footnotetext{
${ }^{36}$ https://news.gov.scot/news/jmc-meeting-on-brexit

${ }^{37} \mathrm{~S}$ Douglas-Scott in this volume.

${ }^{38}$ Notification of Withdrawal (n 12).

${ }^{39}$ Lancaster House Speech (n 6) 13.

${ }^{40}$ White Paper (n 10) [12.3].
} 
negotiations begin within the two-year period this will be a long process, such that the UK will not know whether the trade deal is worth taking when it needs to decide on acceptance of the withdrawal agreement.

The 'no deal' scenario has, moreover, been criticized by the select committee on Exiting the European Union. It was of the view that this would be bad for the UK and the EU, and it was critical because the government had not explained what terms would be demonstrably worse for the UK than 'no deal'. It was therefore incumbent on the Government to "conduct a thorough assessment of the economic, legal and other implications of leaving the EU at the end of the Article 50 period with 'no deal' in place". ${ }^{41}$

\section{(b) Substance}

(i) Withdrawal Agreement: Likely Content

There is no rigid, predefined divide between the two agreements contemplated by Article 50, save for the fact that the withdrawal agreement is essentially backward looking, while the trade agreement is essentially forward looking. The divide could nonetheless vary significantly, given the inherent ambiguity of Article 50(2), to the effect that the withdrawal agreement can take account of the framework for the state's future relationship with the EU. The reality is, however, that hard Brexit naturally inclines to a thin withdrawal agreement, with many issues left for resolution through the future trade agreement. The withdrawal agreement is therefore likely to cover the minimum for a divorce, money, people and borders.

\footnotetext{
${ }^{41}$ Select Committee on Exiting the European Union, The Government's negotiating objectives: The White Paper (HC 1125, 2017) [293].
} 
These issues were identified in the European Council guidelines, and Commission negotiation mandate. ${ }^{42}$

Money matters and will feature prominently in the withdrawal negotiations. The financial settlement will cover liabilities, including contingent liabilities, concerning the Union budget; the termination of the UK's membership in all EU institutions or bodies; the UK's participation in EU funds dealing with specific EU policies; and the cost of moving EU agencies currently located in the UK. ${ }^{43}$ The Commission negotiating mandate emphasizes detailed supervision over payment of these liabilities, ${ }^{44}$ the upper estimates being in the range of 60 billion euros or perhaps more. The ultimate bill will be determined as much by politics as by accountancy, since both sides will be playing to their respective political constituencies.

People matter too, pre-eminently so, and the withdrawal agreement will address the rights of EU citizens living in the UK, and UK citizens residing in the EU. Both sides regard this issue as important. It featured prominently in UK documentation. ${ }^{45}$ President Tusk emphasized the need to think of people first, and to settle "their status and situations after the withdrawal with reciprocal, enforceable and non-discriminatory guarantees", ${ }^{46}$ and MEPs laid similar stress on this issue. ${ }^{47}$ While there is, therefore, consensus on the need to resolve this issue the devil is, as always, in the detail. There are background political pressures, since hard Brexiteers, committed to control over immigration, will not readily accept a solution that accords large numbers of recent EU citizens rights to stay in the UK, and access to social/health care benefits. The European Council guidelines stressed, however, that

\footnotetext{
${ }^{42}$ European Council (n 19) [8]-[21]; Commission Negotiating Mandate (n 23) Annex 1.

${ }^{43}$ Commission Negotiating Mandate (n 23 ) Annex 1, [24]-[26].

${ }^{44}$ Ibid [30].

${ }^{45}$ Lancaster House Speech (n 6) 7; White Paper (n 10) [6.1]-[6.4]; Notification of Withdrawal (n 12) 4.

${ }^{46}$ Remarks by President Donald Tusk (n 15).

${ }^{47}$ Red Lines on Brexit Negotiations (n 18).
} 
guarantees for EU citizens in the UK "must be effective, enforceable, non-discriminatory and comprehensive, including the right to acquire permanent residence after a continuous period of five years of legal residence". ${ }^{48}$ This has been further emphasized in the Commission negotiating mandate, which specified that the agreement must cover economic and noneconomic migrants, and their family members. It set out a detailed list of rights that must be secured, including rights to residence and work; the right to take-up and pursue selfemployment; rights to social welfare benefits; equality in relation to social and tax advantages; and the continued recognition of qualifications. ${ }^{49}$

Borders constitute the third topic in the withdrawal agreement, with the focus on the need to avoid a hard border between Northern Ireland and Ireland. ${ }^{50}$ This was a constant feature in communications from the UK. ${ }^{51}$ It was echoed by President Tusk who spoke of the need to "seek flexible and creative solutions aiming at avoiding a hard border between Northern Ireland and Ireland", 52 and the European Parliament. ${ }^{53}$

There is, therefore, much to resolve concerning money, people and borders. There are, in addition, further issues, such as cases pending before the CJEU at the date of withdrawal, and administrative issues pending before the Commission. ${ }^{54}$ There is, moreover, the question of dispute resolution under the withdrawal agreement. The European Council guidelines state that the choice of this mechanism should be made "bearing in mind the Union's interest to effectively protect its autonomy and its legal order, including the role of the Court of Justice

\footnotetext{
${ }^{48}$ European Council (n 19) [8].

${ }^{49}$ Commission Negotiating Mandate (n 23) Annex 1, [21]-[22].

${ }^{50}$ See the discussion by Doyle and Connolly in this volume.

${ }^{51}$ White Paper (n 10) [4.1]-[4.10]; Notification of Withdrawal (n 12) 5.

${ }^{52}$ Remarks by President Donald Tusk (n 15).

${ }^{53}$ Red Lines on Brexit Negotiations (n 18).

${ }^{54}$ Commission Negotiating Mandate (n 23) Annex 1, [34]-[38].
} 
of the European Union" ${ }^{55}$ This is reinforced by the Commission negotiating mandate, which states that the CJEU must have jurisdiction in relation to the terms of the withdrawal agreement that concern EU law, including citizens' rights and financial liabilities, and that an alternative adjudicative mechanism would only be acceptable for disputes on other matters if it offered equivalent guarantees of independence and impartiality. ${ }^{56}$

\section{(ii) Future Relations: Likely Content}

The agreement on future relations that is envisaged by Article 50(2) may well go beyond trade issues to encompass matters such as such security cooperation and the like. ${ }^{57}$ The present discussion will focus on the trade dimension, which is central to these future relations. The conclusion of free trade agreements is a complex process at the best of times, and this is not the best of times. Even if a withdrawal agreement covering the preceding issues is secured within the two-year time frame, the European Council guidelines on trade are framed in terms of "an overall understanding on the framework of the future relationship", ${ }^{58}$ and the fact that the discussion during the second phase of the negotiations will be "preliminary and preparatory". ${ }^{9}$ The Commission will produce a more detailed negotiating mandate for the second phase if and when matters get to that stage. ${ }^{60}$

The UK government made the decision not to seek membership of the single market, since it required acceptance of free movement of people. The government also decided not to pursue a customs union deal, since it would unduly circumscribe the UK's ability to enter

\footnotetext{
${ }^{55}$ European Council (n 19) [17].

${ }^{56}$ Commission Negotiating Mandate (n 23) Annex 1, [42].

${ }^{57}$ See D Curtin in the present volume.

${ }^{58}$ European Council (n 19) [5].

${ }^{59}$ Ibid [5].

${ }^{60}$ Commission Negotiating Mandate (n 23) Annex 1, [19].
} 
trading arrangements with other parties. These choices have consequences, most notably that the future trade relationship to which Article 50 adverts is a clean slate. The UK government portrayed a far-reaching and comprehensive trade agreement as something that should follow readily from the commonality in regulation between the UK and the EU, coupled with enlightened economic self-interest of both parties. Thus Theresa May, echoing earlier statements, ${ }^{61}$ spoke of a bold and ambitious free trade agreement, while seeking to facilitate its passage by noting that the UK and EU have the same regulatory standards given the UK's membership of the EU. ${ }^{62}$ This is a natural negotiating stance, but it does not capture reality.

The European Council guidelines emphasize the EU's interest in negotiating a future trade deal, subject to the qualifications that it cannot amount to participation in the single market; that it excludes participation in the single market on a sector-by-sector approach; and that a "non-member of the Union, that does not live up to the same obligations as a member, cannot have the same rights and enjoy the same benefits as a member". ${ }^{63}$ The guidelines also state that any trade deal must ensure "a level playing field, notably in terms of competition and state aid, and in this regard encompass safeguards against unfair competitive advantages through, inter alia, tax, social, environmental and regulatory measures and practices", ${ }^{64}$ thereby responding to the UK's suggestion that it might become a low-tax haven if it did not obtain a trade agreement from the EU.

It is important to realize that free trade deals do not come in only one size. The core of a free trade agreement is the abolition of tariffs and quotas on goods. Beyond that the content is diverse in the extreme. It may be relatively simple, but normally is not, since FTAs cover

\footnotetext{
${ }^{61}$ White Paper (n 10) [8.2].

${ }^{62}$ Notification of Withdrawal (n 12) 5.

${ }^{63}$ European Council (n 19) [1], [21].

${ }^{64}$ Ibid [21].
} 
issues such as technical barriers to trade, phytosanitary matters, rules of origin, investment, safeguards, cross-border trade, the environment, customs administration and the like. The more ambitious trade agreements aim for liberalization in areas such as services and investment, cover intellectual property rights and competition, and include provisions on labour and environmental standards. ${ }^{65}$ The US-Australia agreement is 264 pages long, and this is about par for the course, with intricate detail filling every page. This is dwarfed by the EU-Canada Comprehensive Economic and Trade Agreement, CETA, which took seven years to negotiate. It is in excess of 1500 pages, and this is so even though its coverage of services is limited. ${ }^{66}$

The economic reality is that an FTA in a post-Brexit world with the EU would have to include services, since if it did not then its significance would be greatly diminished. This is reflected in the withdrawal letter, which was framed in terms of a bold and ambitious FTA that would include financial services and network industries. ${ }^{67}$ The government's oft-repeated desire is that the FTA should be concluded within the two-year period. ${ }^{68}$ This is unlikely to occur, given the complexity of the negotiations required to secure such a far-reaching deal. This is so even if discussion of the trade agreement takes place in parallel with the withdrawal agreement, which is unlikely to occur. It could take anywhere in the order of fivesix years, before the terms of an ambitious FTA are secured. Such an agreement will, moreover, almost certainly be a mixed agreement, the implications of which will be considered in stage three. There are many other complexities concerning UK-EU trade

\footnotetext{
${ }^{65}$ http://www.trade.gov/fta/ ; https://ustr.gov/trade-agreements/free-trade-agreements/australian-fta

${ }^{66} \mathrm{http}: / /$ ec.europa.eu/trade/policy/in-focus/ceta/

${ }^{67}$ Notification of Withdrawal (n 12) 5.

${ }^{68}$ White Paper (n 10) [12.2-12.3]; Notification of Withdrawal (n 12) 6.
} 
relationships in a post-Brexit world, which go beyond the scope of this chapter. ${ }^{69}$ The UK cannot conclude FTAs with other countries while still in the EU.

\section{Outcomes}

\section{(a) Process}

(i) EU Level

The process for the conclusion of the withdrawal agreement is clear: a withdrawal agreement is concluded on behalf of the EU by the Council acting by qualified majority, after obtaining the consent of the European Parliament. Treaty rights and obligations apply until the agreement is concluded, or until two years from the date of notification, unless the European Council unanimously agrees to extend that period, and the withdrawing state also wishes to extend the time frame.

The process requirements for a trade agreement of the kind desired by the UK are more problematic, because it would almost certainly be a mixed agreement under EU law, ${ }^{70}$ since the subject matter of the agreement would go beyond the EU's exclusive external competence. ${ }^{71}$ It would require ratification by the twenty-seven Member States, plus the regions of some states, as well as the EU. This could well be difficult, but it would not alter the need to secure such separate ratifications. ${ }^{72}$

\footnotetext{
${ }^{69} \mathrm{G}$ Sacerdoti in this volume.

${ }^{70} \mathrm{P}$ Koutrakos and C Hillion, Mixed Agreements Revisited: The EU and its Member States in the World (Hart, 2010).

${ }^{71}$ See the Opinion of Advocate General Sharpston for the complexity of the issues that can arise, Opinion 2/15, Conclusion of the Free Trade Agreement between the European Union and Singapore, 21 December 2016.

${ }^{72} \operatorname{Ibid}[566]$.
} 
(ii) UK Level

It has been contended, in what is known as the Three Knights Opinion, ${ }^{73}$ that the enactment of the European Union (Notification of Withdrawal) Act 2017 does not suffice to entitle the executive to commit to a withdrawal agreement, or to leave the EU in the absence of an agreement, without securing statutory approval. ${ }^{74}$ This decision, it is argued, can only be made when the consequences for the rights of British citizens and businesses are clear, which cannot be known two years in advance of withdrawal. ${ }^{75}$ Parliamentary sovereignty and the principle of legality therefore require Parliament "expressly to authorise withdrawal on the terms agreed with the European Union, or to authorise withdrawal if no acceptable terms can be agreed". ${ }^{76}$ The 2017 Act authorized the Prime Minister to notify the UK's intent to leave the EU, but did not remove rights, or change domestic law, ${ }^{77}$ hence the need for a further statute. ${ }^{78}$ It is argued, moreover, that Article 50 permits a Member State to revoke notification unilaterally if the state's constitutional requirements are not met. ${ }^{79}$

\footnotetext{
73 'In the Matter of Article 50 of the Treaty on European Union'. The title is explicable because three of the authors are renowned EU scholars, who are also knights; Sir David Edward, Sir Francis Jacobs, and Sir Jeremy Lever. There are two other authors, Helen Mountfield QC and Gerry Facena QC.

${ }^{74}$ Ibid [2.i.], [23], [35].

${ }^{75}$ Ibid [2.ii], [20]-[21], [35].

${ }^{76}$ Ibid [2.iii], [35].

${ }^{77}$ Ibid [21].

${ }^{78}$ Ibid [22], [36]-62].

${ }^{79}$ Ibid [2.vi], [2.vii].
} 
Mark Elliott ${ }^{80}$ takes issue with the argument that only legislation enacted at the end of the negotiation process can authorize Brexit. He contends that this is inconsistent with the reasoning in Miller. Elliott argues that it was central to the Miller decision that notification could lead to the loss of rights associated with EU membership, there was a causal link between the two, and that it was for this reason that the Supreme Court decided that Parliament had to authorise the pulling of the trigger. The reasoning in the Three Knights' Opinion was, says Elliott, premised on the claim that no loss of rights was occasioned by triggering Article 50, because rights could not be removed except by legislation enacted when the terms of withdrawal were clear. Mark Elliott contends that this is inconsistent with the premise in Miller that notification in itself could take away rights.

The judicial reaction to any such legal challenge remains to be seen, and it must be recognized that even if a court were to decide in accord with the Three Knights' Opinion the government could probably secure the requisite statutory approval without undue difficulty. There is, however, no inconsistency between the reasoning in Miller and that in the Opinion. The former stands for the proposition that Parliamentary authorization should be required before triggering withdrawal, because of the impact that this could have on rights. It is unclear what rights would be impacted before negotiations start, but the normative premise is that Parliament might not wish to begin such a process because of the possible implications for rights. The reasoning in the Opinion stands for the proposition that statutory authorization should be required when the detailed impact on rights is known. The normative premise at this stage is that Parliament might believe that the detailed agreement placed before it should not be made because the effect on rights, combined with the other terms of the agreement, was unacceptable. To put the same point in a different way, statutory authorization at the first

\footnotetext{
80 Mark Elliott, The Three Knights' Opinion on Brexit: A Response https://publiclawforeveryone.com/2017/02/17/the-three-knights-opinion-on-brexit-a-response/
} 
stage ensures parliamentary voice as a condition precedent to initiating withdrawal, since the impact on rights might be felt to be too far-reaching to warrant inception of withdrawal talks at all; statutory authorization at the second stage ensures such parliamentary voice as a condition precedent for concluding withdrawal, since it thereby enables Parliament to make a fully-informed assessment as to the desirability of the withdrawal agreement when the actual impact on rights is known. There is therefore no inconsistency between these two propositions. $^{81}$

\section{(b) Substance: Revocability}

There has been considerable discussion as to whether a withdrawal notice can be revoked prior to the end of the two-year period. ${ }^{82}$ The issue can only be finally determined by the CJEU. I favour revocability for the following reasons.

${ }^{81}$ It would in principle be open to Parliament to authorize notification through a statute that made it unequivocally clear that Parliament was content for a withdrawal agreement to be concluded that impacted on rights without knowing, when the legislation was enacted, the detail of the rights that would be affected. Such a statute might be undesirable, but if it had been expressly drafted in this way it would then obviate the need for subsequent legislation when the detail of the impact of the withdrawal agreement on rights became known. The European Union (Notification of Withdrawal) Act 2017 was not drafted in this manner. To the contrary, it merely provided the Prime Minister with discretion to trigger notification, which she then exercised.

${ }^{82}$ In favour of revocability: C Streeten, 'Putting the Toothpaste Back in the Tube: Can an Article 50 Notification Be Revoked?', UK Const. L. Blog (13 Jul 2016); A Dashwood, 'Invoking Article 50' (InFacts, 18 Jul 2016); House of Lords Select Committee on the Constitution, 'The Process of Withdrawing from the European Union' evidence of D Wyatt and D Edward (HL Paper 138, 2016); J-C Piris, 'Article 50 is not for ever and the UK could change its mind', Financial Times, 1 Sep 2016; A Sari, 'Biting the Bullet: Why the UK Is Free to Revoke Its Withdrawal Notification under Article 50 TEU', UK Const. L. Blog (17 Oct 2016); P Craig 'Brexit: Foundational Constitutional and Interpretive Principles: II' (OxHRH Blog, 28 Oct 2016); T Tridimas, 'Article 50: An Endgame without an End?' (2016) King's Law Journal 297; A Sari, 'Reversing a Withdrawal 
First, the decision to withdraw must be in accord with the constitutional requirements of the Member State. These may include parliamentary approval of the withdrawal agreement, or a referendum when such terms are known, assuming that these occur within the two-year time frame. If the notice to withdraw could not be revoked, then a state could be forced to leave the EU contrary to its constitutional requirements, since parliamentary approval, or the positive referendum vote, might not be forthcoming. This would be inconsistent with Article 50(1). A national constitutional court might, moreover, conclude that an interpretation of Article 50 that rendered national constitutional requirements otiose precluded ratification of the Lisbon Treaty.

Secondly, irrevocability could have far-reaching negative consequences for the Member State. Irrevocability would mean that nothing could be done to address a financial crisis caused by a withdrawal notice. It would also mean that if there were an election during the two-year period, a successful pro-remain party could do nothing to prevent withdrawal.

Thirdly, irrevocability could also have far-reaching negative consequences for the EU, for example where notice of withdrawal led to serious economic consequences across the Union. There would, moreover, be considerable gain to the EU if a Member State decided to

Notification under Article 50 TEU: Can the Member States Change their Mind?' (Exeter Law School Working Paper Series, 19 Nov 2016); P Eeckhout and E Frantziou, 'Brexit and Article 50 TEU: A Constitutionalist Reading' (UCL European Institute Working Paper, Dec 2016); Three Knights Opinion (n 73). See also, 'Speech by President Donald Tusk at the European Policy Centre conference’ (Speech 575/16, 13 Oct 2016); J-C Junker, Answer given by President Juncker on behalf of the Commission in response to European Parliamentary question p-008603/2016 (17 Jan 2017). Against revocability: N Barber, T Hickman and J King, 'Pulling the Article 50 'Trigger': Parliament's Indispensable Role', UK Const. L. Blog (27 Jun 2016); J Rylatt, 'The Irrevocability of an Article 50 Notification: Lex Specialis and the Irrelevance of the Purported Customary Right to Unilaterally Revoke' UK Const. L. Blog (27 Jul 2016); S Smismans, 'About the Revocability of Withdrawal: Why the EU (Law) Interpretation of Article 50 Matters', UK Const. L. Blog (29 Nov 2016). 
remain in the EU when on the brink of departure, having realized the benefit of membership. This is based on the assumption that the state is acting bona fide and in accord with the principle of sincere cooperation.

Fourthly, irrevocability does not comport with the drafting history of Article $50,{ }^{83}$ which was derived from Article I-60 of the Constitutional Treaty, and was headed 'Voluntary Withdrawal from the Union'. Lord Kerr, who was responsible for drafting that provision with Giuliano Amato, has stated that it was intended to provide a procedural framework for the pre-existing right of a Member State to leave the EU of its own free will, and that such a decision was revocable. ${ }^{84}$

Fifthly, the preceding arguments draw support from the Vienna Convention on the Law of Treaties, VCLT, Article 68 of which provides that "a notification or instrument provided for in article 65 or 67 may be revoked at any time before it takes effect". Article 65 VCLT covers a withdrawal notice. There is disagreement as to whether this is also customary law. The present argument is not dependent on an affirmative answer to that point. The argument is that the architecture of Article 50 TEU is informed by VCLT principles; and that the VCLT shows that there is nothing illegitimate about revocability. Notification under Article 50 TEU only takes legal effect when the withdrawal agreement is concluded, or two years has elapsed.

Finally, it is argued that revocability would allow a state to revoke in the $23^{\text {rd }}$ month, make a new notice of withdrawal, and thus begin another two-year cycle. This argument is based on the implausible assumption that the state would get a better deal second time round. The other Member States would, however, regard such action as illegitimate, and refuse to shift from the pre-existing offer. The courts could, moreover, prevent such abuse. The CJEU

\footnotetext{
${ }^{83}$ For analysis of the travaux préparatoires in the Constitutional Treaty, see, Eeckhout and Frantziou (n 82).

${ }^{84}$ BBC website 3 Nov 2016 http://www.bbc.co.uk/news/uk-scotland-scotland-politics-37852628
} 
could conclude that such behaviour was designed to circumvent the two-year time period; that it undermined the need for unanimity to extend that period; with the consequence that the state would only have one month before the two-year period expired. This argument could be reinforced by the principle of sincere cooperation in Article 4(3) TEU.

If the notice given under Article 50 were to be revocable there would be further inquiry as to whether it should be revocable unilaterally, by qualified majority or by unanimity. My own preference is for unilateral revocability, although a requirement of qualified majority, which is the test for EU assent to a withdrawal agreement, could be used if it were felt that this was required to protect the EU's interest.

The importance of this issue to the UK political process cannot, however, be doubted. If Article 50 were revocable then Parliament could in principle decide to revoke the notification of withdrawal, and/or call a second referendum, but the interpretation of Article 50 as irrevocable means that Parliament has no leverage at this point, since once Article 50 is triggered there is no turning back.

\section{(c) Substance: Transition}

While there has been considerable discussion concerning revocability, this is not so in relation to transitional agreements. In truth the government has equivocated in this regard. It has contended that withdrawal and trade agreements can be concluded in two years. ${ }^{85}$ It has also spoken of the need for "implementation periods to adjust in a smooth and orderly way to new arrangements". ${ }^{86}$ While the political reality is that a transitional agreement may be

\footnotetext{
${ }^{85}$ Notification of Withdrawal (n 12) 6.

${ }^{86}$ Notification of Withdrawal (n 12) 4.
} 
needed, its legality is uncertain. ${ }^{87}$ The European Council spoke of a transition agreement to the extent to which it was necessary and legally possible. ${ }^{88}$ It might assume three different forms.

\section{(i) Transition and Change}

A transitional agreement might be directed to the future, providing a bridge between the status quo and the future agreement, the details of which may not be concluded within two years. This is the assumption in the Commission negotiating mandate. ${ }^{89}$ It might be conceived as part of the withdrawal agreement, or as independent thereof. There are, however, difficulties in both respects.

There are substantive issues as to how far transitional provisions concerning future trade could be appended to the withdrawal agreement. Article 50(2) states that the withdrawal agreement can take account of the state's future relationship with the EU, which undoubtedly contains interpretive leeway, but if transitional provisions are to be of practical use they will have to be detailed.

This leads to a procedural difficulty, which is that detailed transitional provisions smoothing future trade relations might not fall within the EU's exclusive competence. They would require ratification by all Member States, following the logic of mixed agreements, and hence could not readily be part of a withdrawal agreement. If ratification in all Member States as well as the EU were required this could lead to considerable delay, hence

\footnotetext{
87 See also, Pavlos Eleftheriadis, "Parallel Sources": How to Construct the Transitional Brexit Arrangement',https://www.law.ox.ac.uk/business-law-blog/blog/2017/02/how-make-transitional-brexitarrangement

${ }^{88}$ European Council (n 19) [6].

${ }^{89}$ Commission Negotiating Mandate (n 23) Annex 1, [19].
} 
undermining the rationale for transitional provisions. This problem would persist even if the transitional agreement were a separate agreement.

\section{(ii) Transition and Continuity}

The concept of transition might alternatively connote continuation of some EU treaty provisions, pending conclusion of a future agreement. If there is no meaningful discussion of future trade relations within the two-year period the concept of transition could not connote a bridge between the old and the new, since by definition the content of the new order would not be known. The existing EU rules provide a framework that would obviate the dangers of the cliff-edge. There will be political challenges in securing acceptance of any deal in the UK and the EU. Such a transitional agreement might be part of the withdrawal agreement, or independent thereof, but there are legal difficulties.

There are substantive issues as to compatibility with the EU legal order. International agreements are regularly scrutinized in this regard..$^{90}$ It would therefore have to be decided whether continuation of some EU provisions was compatible with the EU Treaty, and its underlying principles, which would be determined by the CJEU. The CJEU would, moreover, have jurisdiction over the transitional provisions. Denial of its interpretive authority over Treaty provisions during a transitional period would be regarded as infringing the autonomy

90 Opinion 1/00, Proposed Agreement between the European Community and non-Member States on the establishment of a European Common Aviation Area [2000] ECR I-3498, [12]-[13]; Opinion 1/91, Draft agreement between the Community, on the one hand, and the countries of the European Free Trade Association, on the other, relating to the creation of the European Economic Area, EU:C:1991:490, [61] -[65]; Opinion 1/92, Draft agreement between the Community, on the one hand, and the countries of the European Free Trade Association, on the other, relating to the creation of the European Economic Area, EU:C:1992:189, [32], [41]; Opinion 2/13, Draft international agreement - Accession of the European Union to the European Convention for the Protection of Human Rights and Fundamental Freedoms, EU:C:2014:2454, [201]. 
of the EU legal order. ${ }^{91}$ As the European Council guidelines noted, prolongation of the EU acquis "would require existing Union regulatory, budgetary, supervisory, judiciary and enforcement instruments and structures to apply". ${ }^{92}$

There are, moreover, procedural problems if the transitional provisions are appended to the withdrawal agreement. Article 50(3) provides that the Treaties cease to apply to the Member State from the date when the withdrawal agreement enters into force. This creates a Catch 22. The agreement must be legally in force for the transitional provisions to apply. However, when the agreement enters into force Article 50 stipulates that the Treaties cease to apply. There is no provision allowing some of the Treaty articles to continue pending completion of a trade agreement at an unspecified future date.

It is, moreover, questionable whether a withdrawal agreement could perpetuate some provisions of membership beyond two years, given that the voting rules for the withdrawal agreement only require a qualified majority, whereas unanimity is the criterion for extension of the time to secure a withdrawal agreement over and beyond two years. A withdrawal agreement concluded by qualified majority that did not terminate all the withdrawing state's rights and obligations on the date when the agreement took effect could be regarded as circumventing the unanimity requirement in Article 50(3) for an extension beyond the twoyear period.

\section{(iii) Transition, Change and Continuity}

The third possibility is that a transitional agreement is in part continuation of the past, in part a window to the future. This is likely, given that the first option is predicated on the assumption that the future trade relationship has been worked out to some degree. There may,

\footnotetext{
${ }^{91}$ Opinion 2/13 (n 90) [205].

${ }^{92}$ European Council (n 19) [6].
} 
however, be scant by way of agreement on future trade relations within the two-year period, or the terms may be exiguous in the extreme, such that the transition would perforce be directed in part towards continuation with the EU status quo, and in part to smoothing the path towards whatever might have been concluded on trade relations. The legal concerns associated with transition and change, and those associated with transition and continuity, would both be relevant.

\section{Conclusion}

The Brexit negotiations will be an acute mix of the political and the legal. It remains to be seen whether a deal is secured. The trajectories are more complex than commonly imagined.

The conclusion could be no withdrawal agreement, and no trade agreement. The consequence would be a plethora of unresolved issues concerning matters such as the UK's financial liabilities, the rights of EU citizens in the UK and UK citizens in the EU. The UK would default to WTO trade rules, and a future EU trade relationship would be more difficult if the talks on withdrawal were acrimonious and unresolved.

The conclusion could be a withdrawal agreement dealing with the issues adumbrated above, but scant progress on future trade relations. Much would then turn on whether a transitional agreement on trade could be concluded. If it could not, then the WTO would become applicable on trade matters pending conclusion of a trade deal between the UK and the EU.

The third possibility is that a withdrawal agreement and a comprehensive trade agreement can be secured within the two period. The likelihood of this transpiring is, however, remote, given the phased approach to the Brexit negotiations, coupled with the fact that a comprehensive trade agreement will require lengthy discussion and ratification by all twenty-seven Member States. 
